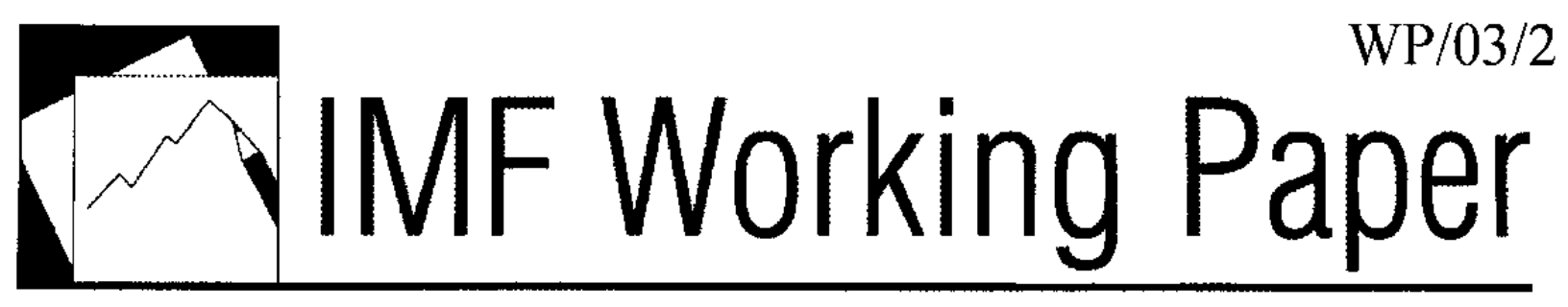

\title{
A Comparison Between Two Public Expenditure Management Systems in Africa
}

Ian Lienert 


\title{
IMF Working Paper
}

\author{
Fiscal Affairs Department
}

\section{A Comparison Between Two Public Expenditure Management Systems in Africa}

\author{
Prepared by Ian Lienert ${ }^{1}$ \\ Authorized for distribution by Jack Diamond
}

January 2003

\begin{abstract}
The views expressed in this Working Paper are those of the author(s) and do not necessarily represent those of the $\mathrm{MM}^{7}$ or $\mathrm{MMF}$ policy. Working Papers describe research in progress by the author(s) and are published to elicit comments and to further debate.
\end{abstract}

This paper assesses the advantages and disadvantages of the French and British public expenditure management systems as used in Africa. The main differences are in budget execution and government accounting. In both francophone and anglophone Africa, there are common weaknesses in the application of the inherited systems, which appear to dominate any distinct features of the individual systems. Desirable reforms in both systems will only be successful if they are accompanied by measures that enhance the accountability of those who operate the systems, including enforcing the rules embodied in existing or reformed regulatory frameworks.

JEL Classification Numbers: E62, H11, H30, H50, H61, N47, O23, P51

Keywords: public expenditure management, budget system, audit, British, French, Africa

Author's E-Mail Address: ilienert@imforg

\footnotetext{
1 The author wishes to thank colleagues of the Fiscal Affairs Department, particularly Messrs. Bouley, Diamond, Khemani, Ms. Fedelino and Ms. Jacobs for helpful comments for preparing this paper. He is particularly grateful to Mr. Mike Stevens for extensive comments and other World Bank colleagues, including Mr. de Chazal. Finally, thanks is expressed to Mr. Potter, Director, IMF's Office of Budget and Planning, who initiated this paper when he was chief, Public Expenditure Management Division, FAD.
} 
I. Introduction .3

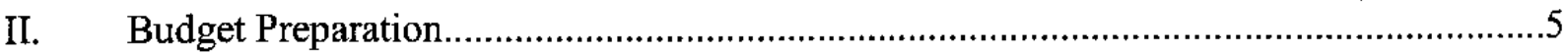

A. Legislative Basis for Budget Preparation.........................................................

B. Common Features of Budget Preparation in the Two Regions...................................6

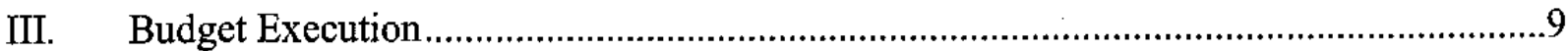

A. Key Actors in the Expenditure Process and Their Respective Roles ........................9

B. Expenditure Control .................................................................................... 12

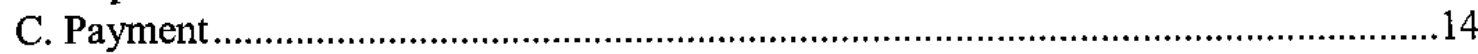

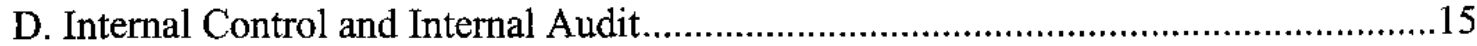

IV. Government Accounting, Banking and Fiscal Reporting ..........................................16

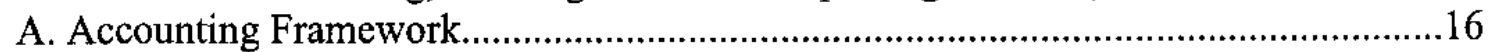

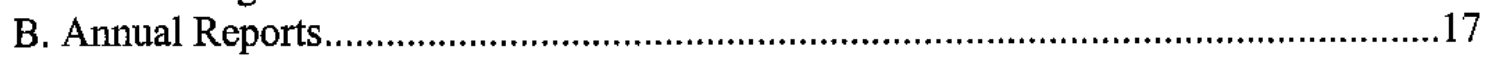

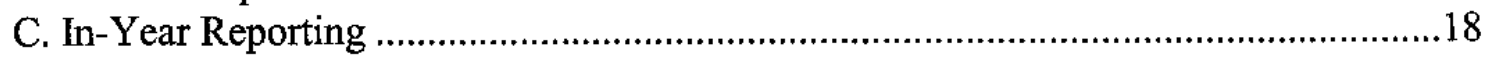

D. Government Banking Arrangements ...................................................................19

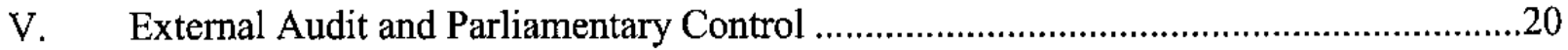

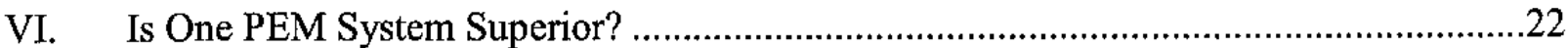

A. Potential Strengths of the Individual PEM Systems ..........................................22

B. Common Weaknesses of PEM Under Both Systems.........................................29

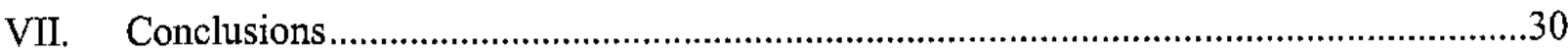

Text Table

1. Distinctive Features that are Potential Strengths of PEM Systems ............................23

Figures

1. Relative Performance of PEM Systems in Africa.................................................4

2. Influence of Ministry of Finance and Spending Ministries in Budget Execution ..........10

3. Key Differences in Budget Execution and Expenditure control..................................13

Boxes

1. Common Features of Budget Preparation Systems in Francophone and Anglophone Africa...................................................................................

2. Responsibilities of Accounting Officers in Spending Ministries of Anglophone

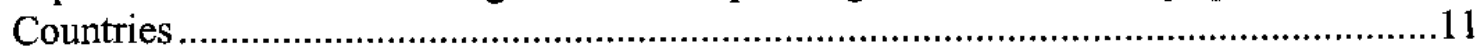

3. Key Similarities and Differences in Accounting and Banking Arrangements ...............16

4. Exceptional Expenditure Procedures in Francophone Countries.................................24

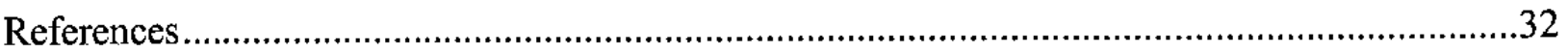




\section{INTRODUCTION}

Many African countries are benefiting from reductions in their external debt. One important objective is to redirect the budgetary resources released from servicing external debt towards poverty-reducing expenditures. Several questions arise in this context. First, are African countries' public expenditure management (PEM) system robust enough to allow specific poverty-reducing expenditures to be identified in annual budgets and tracked in countries' accounting systems? Second, does the expenditure control system allow poverty-reducing expenditures to be protected from cuts should there be unforeseen shortfalls in revenues? Third, are internal and external audit mechanisms effective, so as to ensure the integrity of expenditure reports, both in-year and annually? To answer these, and other questions, an assessment of the entire PEM system is required in each country.

Such a study has already been prepared. ${ }^{2}$ During 2001, 24 low-income countries' PEM systems were assessed, based on a common set of 15 questions in the three areas of budget preparation, budget execution, and fiscal reporting. Figure 1 shows the resultsboth regions attained only about 40 percent of the required benchmarks-well below that required to meet the objectives of effective PEM systems.

This paper focuses on one question: "Are there features of a specific PEM system in Africa that consistently performs better than other systems?" Since most countries in Africa have inherited either a French-based or a British-based PEM system, the comparison is limited to these two systems. ${ }^{3}$ Other studies have documented the common weaknesses of the anglophone and francophone PEM systems, respectively. ${ }^{4}$ This paper complements this research by conducting a comparative analysis. Sections II to V review the major features of these two PEM systems. The key differences between the two PEM systems in each of these areas are identified. Section VI discusses the advantages and disadvantages of one system over the other. It is concluded in Section VII that any potential advantages of one system are nullified by the way that the systems are operated.

A paper of this nature necessarily includes generalizations: countries within the two zones have experienced different developments of their PEM systems since independence from the colonial powers. This paper is also based on the countries that have benefited

\footnotetext{
${ }^{2}$ See IMF (2002), "Actions to Strengthen the Tracking of Poverty-Reducing Public Spending in HIPCs," March 22, 2002, www.imf.org.

${ }^{3}$ Lusophone countries inherited a Portuguese-based system and the Democratic Republic of the Congo, Rwanda, and Burundi inherited a Belgian PEM system (it differs somewhat from the French-based system). ${ }^{4}$ For example, see Lienert and Sarraf (2001) for weaknesses in anglophone African countries, and Bouley et al. (2002) and Moussa (forthcoming) for weaknesses in francophone African countries.
} 
Figure 1. Relative Performance of PEM Systems in Africa

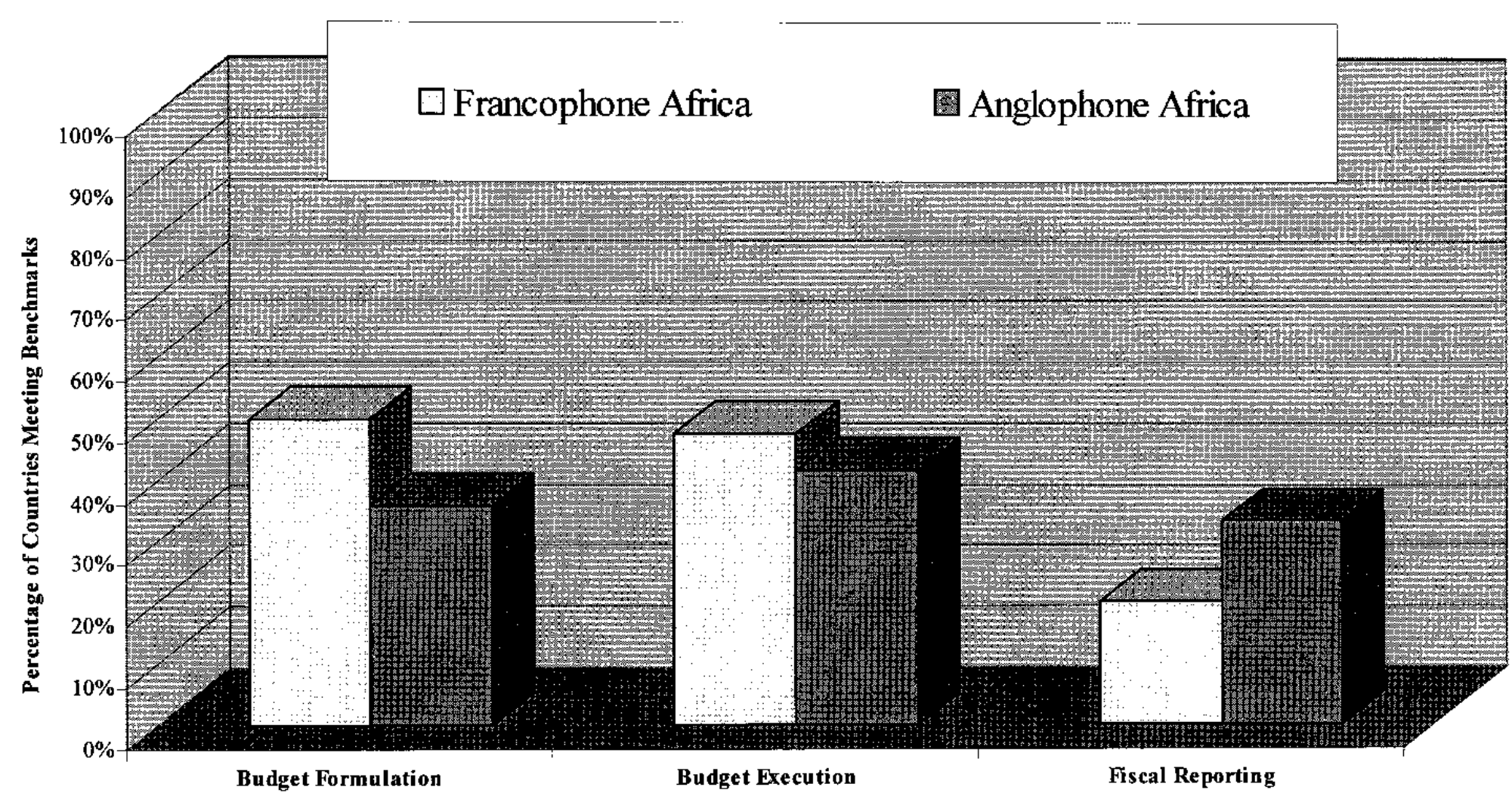

Note: 15 benchmarks were established: 7 for budget formulation and 4 each for budget execution and fiscal reporting. See IMF (2002).

The francophone countries in the sample are: Benin, Burkina Faso, Cameroon, Chad, Guinea, Madagascar, Mali, Mauritania, Niger, and Senegal.

The anglophone countries in the sample are: The Gambia, Ghana, Malawi, Tanzania, Uganda, and Zambia. 
from IMF technical assistance over the past decade. ${ }^{5}$ The emphasis is therefore on describing or evaluating how PEM systems actually operate, rather than how they ought to operate on the basis of each system's regulatory framework.

\section{Budget Preparation}

This section first examines the legislative framework for budget-making, as it provides the foundation of the budget preparation system.

\section{A. Legislative Basis for Budget Preparation}

Constitutions in francophone countries typically include a statement that the annual budget law (loi de finances) determines the resources and expenses of the State. They also include provisions on the timing of the presentation of the loi de finances to Parliament (often in October for a budget year that begins on January 1) and permissable actions by the executive branch when the annual budget is not adopted on time by Parliament. Typically, governments may begin executing the new budget on the basis of monthly authorizations equal to $1 / 12$ th of the previous year's budget.

Constitutions of anglophone countries vary considerably in their provisions for the budget process. Some countries may have very few, if any, articles on budgeting in constitutions (e.g., Uganda). Others may have considerably more detail than francophone countries (e.g., Nigeria). A typical constitutional requirement is that money may not be withdrawn from the consolidated fund unless appropriated or provided for by another law (e.g., a public debt law).

In the French-based system, organic budget laws spell out five well-known principles for budget preparation: annual basis, unity, universality, specificity, and equilibrium (balance). ${ }^{6}$ In francophone Africa, organic budget Laws are based largely on that adopted in France in 1959. ${ }^{7}$ They typically define or specify: (1) current and capital expenditures, and loans/advances; (2) the broad categories of the economic classification of expenditures; ${ }^{8}$ (3) the nature of documents to be submitted to Parliament; and (4) procedures for preparing and adopting annual loi de finances.

Budget laws in anglophone countries are dissimilar to those of the francophone countries. The closest equivalent to an "organic budget law" in anglophone countries are "Finance and Audit Acts." Although these may have a chapter on budget preparation, there is strong emphasis on budget execution and ex post audit. In both regions,

\footnotetext{
${ }^{5}$ These are the 15 countries listed in Figure 1, plus Côte d'Ivoire, Kenya, Lesotho, Nigeria, Togo, and Zimbabwe. South Africa is excluded since it is more advanced in budget management than a typical African country.

${ }^{6}$ Attiogbe (1999) recalls these principles for the case of Togo. These principles were developed during the $3^{\text {rd }}$ and $4^{\text {th }}$ French Republics, 1871-1958-see chapter 1 of Lord (1973).

${ }^{7}$ See Ordonnance du 2 janvier, 1959 portant Loi Organique relative aux Lois de finances.

${ }^{8}$ See for example, Directive No. 05/97/CM/WAEMU concerning budget Laws, www.uemoa.int
} 
Ministries of Finances (MOFs) provide guidance to budget preparation, through budget circulars or other administrative notices.

\section{B. Common Features of Budget Preparation in the Two Regions}

The processes involved in budget preparation are similar (Box 1).

Box 1. Common Features of Budget Preparation Systems
in Francophone and Anglophone Africa
- $\quad$ Annual basis for the budget, but no medium-term expenditure framework.
- $\quad$ One budget for current expenditures and another budget for investments.
Detailed line-item budgeting.
The budget is generally limited to central government, plus a few autonomous funds. Local
governments and extrabudgetary funds are excluded.
A process of decentralization of budgeting to lower levels of government is under way.
Unrealistic costings of expenditures: some line items are underprovisioned.
Timing - budget preparation allows little time for parliamentary discussion.
An absence of focus on results or effectiveness of government programs.

Since the abandonment of national planning, ${ }^{9}$ budgets have traditionally only been annual, at least for current expenditures. Few countries have developed functioning medium-term budget frameworks (MTBFs). Nonetheless, in recent years, a beginning has been made in this direction, especially in the anglophone countries (e.g., Ghana, Tanzania, Uganda). In the case of Uganda, a Budget Act was adopted in 2000, which, inter alia, provides legal underpinning for the MTBFs that were elaborated in the $1990 \mathrm{~s}$.

In francophone countries, multiyear budget provisioning for capital expenditures is provided for in organic budget laws. Multiyear budget appropriations (autorisations de programme) allow ministries to commit expenditures for capital projects for periods exceeding one year. Accompanying these appropriations are limits on annual payments (crédits de paiements), which are included in the annual loi de finances. At year-end, any unspent crédits de paiements can be carried over to the new fiscal year. In contrast, in anglophone countries, unspent appropriations are cancelled at year-end and reappropriated in the following year's budget.

${ }^{9}$ In the initial years after independence, many countrics prepared national development plans. Howcver, these were poorly linked with annual budgets and policy debates. 
Donors dominate the size of investment budgets and public investment programs (PIPs) ${ }^{10}$ In both sets of countries, donors finance most investment spending. Although projects in the PIPs should be prioritized according to objective criteria, in practice, donor preferences have heavily influenced the composition of investment budgets. In particular, donors have inserted into national budgets projects which may have served the donor country's interests as much as the African country's.

Dual budgeting has been widespread. Separate budgets are often prepared for current expenditures and "investment" expenditures. The latter-sometimes called "development budgets" - often contain considerable recurrent expenditures. The absence of MTBFs and nonintegrated budgets also result in the failure to appreciate the recurrent expenditure implications of investment projects. It is now recognized that, in both sets of countries, "dual budgeting may well be the most important culprit in the failure to link planning, policy and budgeting"-see Box 3.11 of World Bank (1998).

The budget has traditionally been prepared mainly on a detailed line-item basis. In both regions, the main budget document may run into hundreds of pages. Such detail complicates budgetary management. Budget classification is generally similar: the budget is adopted by organizational classification (e.g., ministry, administrative unit, province) and by economic classification (e.g., salaries, current goods and services, transfers, capital spending-proxied in the "development budget"). It is rare in both regions to classify expenditures by program or by function. In both regions the rules for virementreallocation between budget lines-are well defined, although in practice, they are not always respected.

In both sets of countries, the budget adopted is generally limited to central government. In the annual budget, Parliament approves central government transfers to lower levels of government. Estimates of the revenues of subnational governments are usually not provided as background information. Revenues collected and retained by autonomous agencies (e.g., hospitals) dependent upon budget transfers for their main source of income are often not shown transparently in the budget.

In both regions, semiautonomous budgets, extrabudgetary funds, and off-budget activities are important. In the francophone countries, although organic budget laws refer to the principle of unity of spending from one common fund and universality (all spending should be in the budget), in practice there are several exceptions. In particular, there are budget annexes and special treasury accounts of various types. ${ }^{11}$ Although these are presented to Parliament for adoption and subject to public accounting rules, in practice, poor accounting records are maintained. In anglophone countries, off-budget "below-the-line" funds have caused problems in budget execution in several countries

\footnotetext{
${ }^{10}$ Central government investment budgets are usually a subset of PIPs, as the latter cover all public investment projects, including those executed by local governments and public entreprises.

${ }^{11}$ In most francophone countries, the revenues and expenditures of the Post and Telecommunications Offices are presented as a budget annex to the Loi de finances. The budgets for the National Pension Funds, the Debt Management Agency, and the Social Security Office are not systematically included in the budget.
} 
(e.g., The Gambia, Zimbabwe). Road funds are usually integrated with the budget preparation process, but they are managed autonomously. Social security or pension funds are generally outside the budget preparation process in both regions. ${ }^{12}$

There are often unrealistic projections for revenues and specific expenditures. Revenue projections have often proven to be too optimistic, resulting in shortfalls in resources available to finance budgeted expenditure programs. In addition, specific expenditures are underestimated in the budget. This problem is often acute for budget provisions for utilities (electricity, telephone, water) or other expenditures whose commitment cannot be postponed (e.g., food for the army and for prisoners). In both regions, the data for ministry-specific unit costs and consumption volumes of these items is often of poor quality.

\section{Spending ministries do not comply fully with the Budget Department's budget} circulars to provide well-justified estimates for all expenditures. At the same time, Budget Departments of MOFs often do not critically examine the expenditure estimates. Reasons for this include a lack of staff qualified to provide a "challenge" function and a very tight timetable for bilateral budget discussions at technical level.

Following agreement of the budget at technical level, important political decisions affecting spending may be made late in the budget cycle prior to the budget's adoption by Parliament. Also, political authorities—not necessarily the Minister of Finance-may make decisions during the budget year that weaken the capacity of the MOF to finance the expenditures already approved in the budget adopted by Parliament.

One specific feature of francophone countries is the distinction between existing and new policies. As early as the 1960s, the annual budgets of several francophone countries, showed, for each line-item, a split between existing policies (services votés) and new measures (mesures nouvelles). ${ }^{3}$ However, the quality of the estimates was often not high, as these were often largely based on extrapolations of previous-year budget projections. Nonetheless, a formal distinction between existing and new policies was not part of the system adopted in anglophone Africa.

Budgets are often adopted late in both groups of countries. Although in francophone countries constitutions and/or organic budget laws lay out the key dates for budget presentation and adoption by Parliament, these are not always respected. For example, in Côte d'Ivoire, the budget for 2001, covering January-December was adopted in July 2001. Similarly, in anglophone countries, where budget preparation calendars are also clearly spelt out, the budget may be presented to Parliament just before the beginning of a new fiscal year (e.g., Kenya, Tanzania, Uganda), and not adopted until the second or third month of the new fiscal year (see Fölscher (2002) for a five-country survey). As a consequence, a mid-year review of the budget is not carried out by Parliament.

\footnotetext{
12 One exception are the pension funds for retired civil servants and military.

${ }^{13}$ See page 114 of Autin (1971).
} 
The budget is usually not discussed extensively by Parliament. In the United Kingdom and France, parliamentary budget commissions have traditionally played an active role in examining the budget prior to its formal adoption by Parliament. This has not been the case in Africa, reflecting lack of capacity and inadequate attention to the role of Parliament in the budget process. However, parliamentary budget subcommittees are becoming active in a few francophone countries and several anglophone countries (e.g., Mali, Tanzania, and Uganda), in line with greater democratization.

Performance-oriented budgeting is beginning in both regions (e.g., Mali, Uganda). This is necessitated by the challenge of implementing country-owned poverty-reduction strategies that link specific objectives - especially in education and health-with budgeted expenditures needed to achieve the desired changes. However, the capacity to administer the additional data and analytical requirements of output/outcome budgeting is often lacking. Moreover, where they exist, "programs" are not well conceived; they are often simply a provisioning of present organizational structures within Ministries.

\section{Budget Execution}

In contrast to the considerable similarities of the two PEM systems for budget preparation, when it comes to budget execution, there are some important differences. The key contrasts between the two systems revolve around the degree of (de)centralization of responsibility for budget management to spending ministries. These differences are elaborated below and in successive sections.

\section{A. Key Actors in the Expenditure Process and Their Respective Roles}

The British approach can be characterized as one of decentralized managementspending ministries are mainly responsible for budget execution. In contrast, the French-based system is one in which the central MOF plays an important role at each step of the spending process. The balance of powers and key players are illustrated in Figure 2.

In anglophone countries, officials in spending ministries are charged with initiating and authorizing each step of the expenditure process, from commitment to payment. Following adoption of the budget, the Minister of Finance ${ }^{14}$ issues quarterly or annual warrants to "Accounting Officers" (AOs), who are generally the heads ("Permanent Secretaries") of spending ministries and have extensive responsibilites (Box 2). The warrants convey the legal authority to vote holders to authorize expenditure of public funds. Accounting Officers, in turn, may delegate disbursement authority to officers in their ministry, including those in regional cost centers.

\footnotetext{
${ }^{14}$ Traditionally, this was done via the "Paymaster-General," a high-ranking official of the MOF appointed by the Minister for controlling the issue of public moneys to Accounting Officers.
} 


\section{Figure 2. Influence of Ministry of Finance and Spending Ministries in Budget Execution}

Ministry of Finance

Sector Ministries

\section{A: Anglophone African Countries}

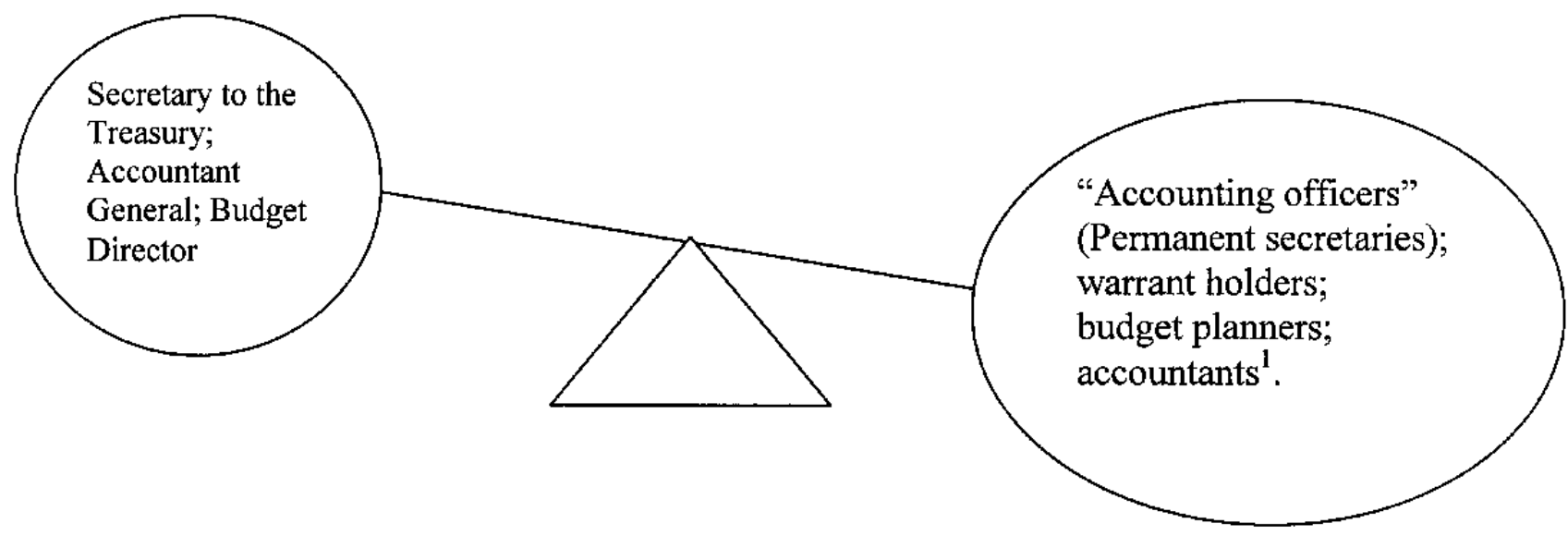

B: Francophone African Countries

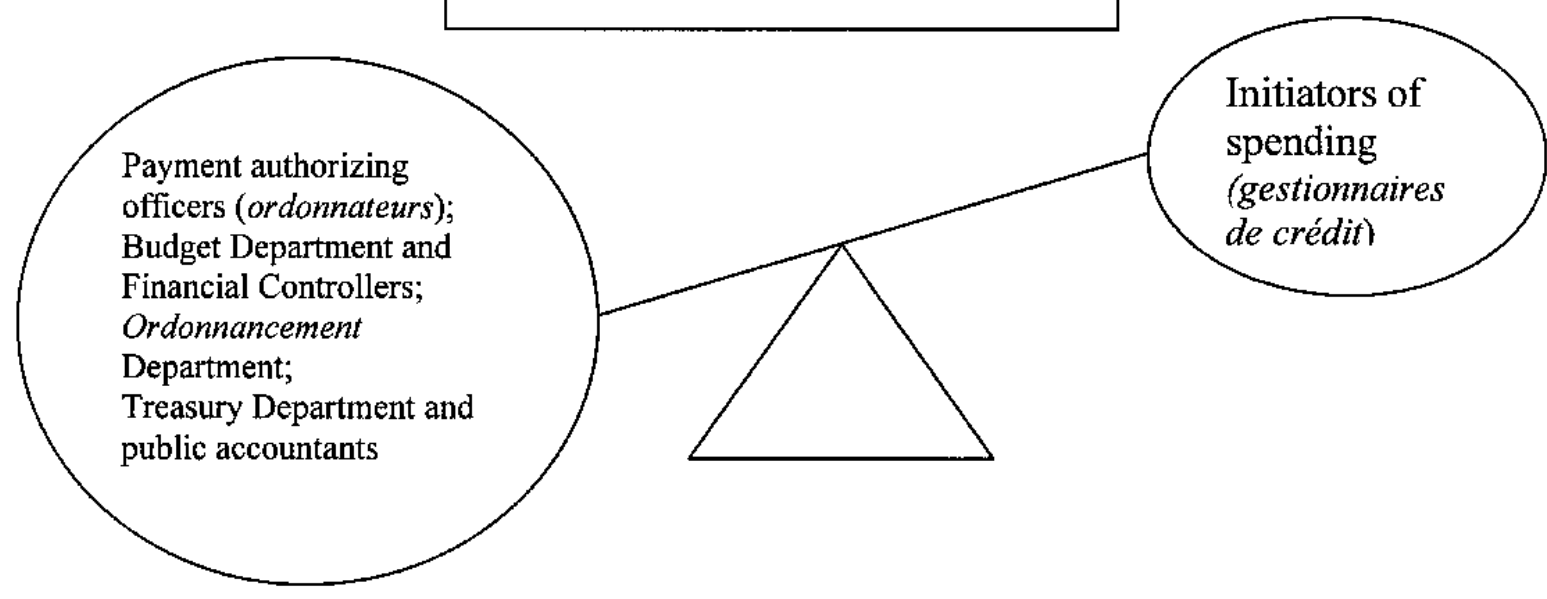

${ }^{1}$ Accountants report to the Accounting Officer of the ministry or agency, but are usually posted to the unit by the Accountant General of the MOF, who sets professional standards. 


\section{Box 2. Responsibilities of Accounting Officers (AOs) in Spending Ministries of Anglophone Countries}

- $\quad$ Preparing budget projections for their Ministry.

- Ensuring that no head of expenditure is exceeded and that no subhead or item is exceeded without proper authority. ${ }^{15}$

- Delegating authority to spend to authorized officers in his/her ministrysubwarrant holders - and ensuring that delegated officers do not overspend.

- $\quad$ Endorsing the Annual Accounts of the Ministry and defending the Ministry's budget outcome before the Public Accounts Committee of Parliament.

In the francophone system, such wide ranging responsibilities are not provided to spending ministries. On the contrary, the closest equivalent to AOs (gestionnaires de crédit) have a rather limited role-mainly that of initiating expenditures at the commitment stage, within the budget provision. They do not have authority to issue payment orders (ordonnancement).

Various departments of the Ministry of Finance of francophone countries play all the important roles in budget exeucution. The key players are: Financial Controllers (contrôleurs financiers), who are generally under the Budget Department of the MOF; payment authorizing officers (ordonnateurs) who approve the issuance of payment orders to the Treasury, ${ }^{16}$ and public accountants (comptables publics) in the Treasury.

A key principle of the francophone PEM system is the separation of the payment authorizing officer and the treasury officer responsible for payment. Since both of these functions are centralized in the MOF, financial management in spending ministries is diluted. In most countries, the Minister of Finance is the sole authorizing officer (ordonnateur unique). ${ }^{17}$ However, the Minister of Finance is also the overseer of the functioning of the Treasury and of public accountants. Thus, despite the principle of the

\footnotetext{
${ }^{15}$ Accounting Officers can generally reallocate funds from one subhead to another within current budgets (but not capital budgets). However, they are not authorized to transfer budget allocations for salaries to nonsalary current expenditures or vice versa.

${ }^{16}$ In some countries sous-ordonnateurs exist for authorizing payment orders at the regional level (e.g., Madagascar) or in specific ministries (e.g.. Ministry of Defense, Mauritania). However, such delegated officers are still under the authority of the ordonnateur principal, usually the Minister of Finance.

${ }^{17}$ The directives by the West African Economic and Monetary Union (WAEMU) to the eight West African francophone countries contain such a provision. This system dates from the time from when there was a single Governor of France in the colony. Upon independence, the governors' powers were transferred to the Ministers of Finance.
} 
separation of the ordonnateur and comptable, the Minister of Finance is both the principal ordonnateur and "chief of staff" of all comptables.

As a consequence, the Minister of Finance has unique powers in expenditure management, without parallel in the anglophone system. The system in Africa is even more centralized than in France, where both Cabinet Ministers and central government representatives at local level (préfets) are ordonnateurs. The system in francophone Africa therefore confers virtually no responsibility for effective financial management on government Ministers or the heads of spending ministries.

\section{B. Expenditure Control}

In the anglophone system, expenditure control is largely exercised by the warrant system. In principle, the MOF can control the issuance of warrants for nonstatutory expenditures. ${ }^{18}$ For example, annual warrants can be provided for salaries, and quarterly or monthly warrants for other current expenditures. Warrant control is a major instrument of expenditure control in some countries (e.g., Kenya, Lesotho). In principle, Accounting Officers record expenditure commitments in their "Vote Books" and should report these to the MOF. This allows for commitments to be controlled. However, in several countries (e.g., Malawi, Zambia), ministries' reports on expenditure commitments are incomplete and received late by the MOF; as a consequence, the MOF has been unable to exercise control over expenditure commitments.

"Cash budgeting" arrangements were introduced in a number of anglophone countries, especially during the 1990 s (e.g., Kenya, Tanzania, Zambia), mainly because expenditure control was not being exercised. ${ }^{19}$ Under this system, cash allocations to ministries are limited to that dictated by cash availability, i.e., the amount that ministries are authorized to spend is subject to cash limits. In practice, since the cash limits were often below the warrant limits - and the latter are consistent with the annual budget appropriations-AOs often did not ensure that expenditure commitments were contained within the cash limits. As a result, expenditure arrears-overdue unpaid invoicesbecame a pervasive problems in many anglophone African countries.

The expenditure control system in francophone countries is quite different, with formal controls at each stage of the expenditure process : commitment, payment order issuance (ordonnancement), and payment (see Figure 3). However, the formal duties exercised by Financial Controllers and the Treasury are limited largely to compliance with budget appropriations: they seldom take into consideration the amount of cash available for expenditure.

\footnotetext{
${ }^{18}$ Statutory expenditures are those which must be paid, irrespective of budget projections, because another law requires it. Included are debt servicing, salaries of certain high officials (e.g., Auditor General), etc. A similar category of budget appropriations exists in francophone countries (crédits évaluatifs).

${ }^{19}$ There were both revenue shortfalls and expenditure overruns. To deal with the former, warrant authority can be withdrawn under the British system. However, in Africa, warrant withdrawal was extremely rare.
} 
Figure 3. Key Differences in Budget Execution and Expenditure Control

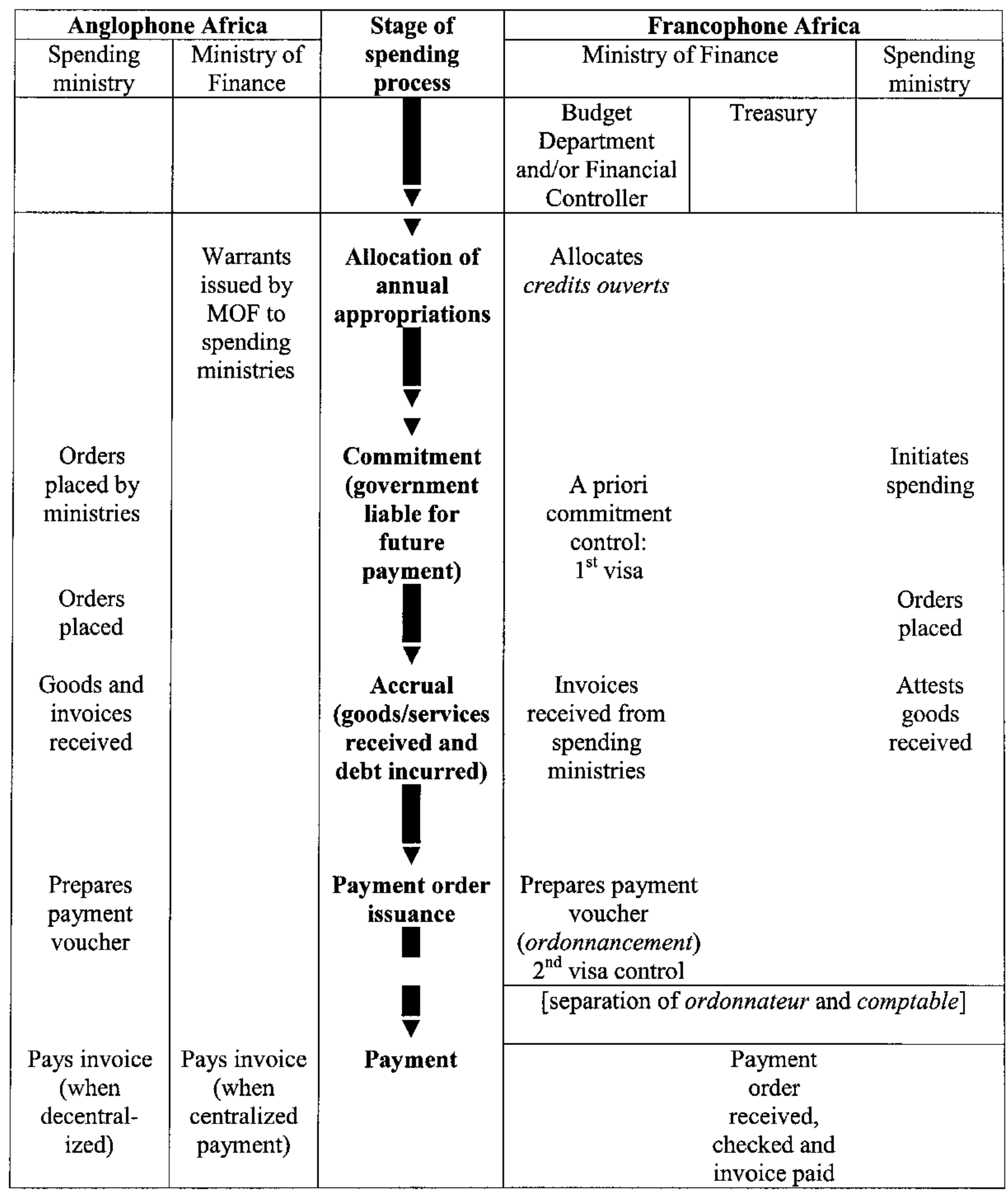


In the francophone countries, controls overlap, and at no stage in the expenditure process is it questioned whether or not the expenditure should take place. The Treasury's "control" of expenditures is limited to checks of the conformity of expenditure payment requests with existing financial regulations. Such checks have already been done twice by the Financial Controller. Also, although the Treasury may provide a visa "good for payment" ( $v u$ bon à payer) on payment vouchers, the Treasury's coffers may be empty and payment arrears arise. This is largely because, in most francophone countries, monthly cash management systems, if developed at all, are poorly integrated with treasury procedures.

Some expenditures in francophone countries do not require formal controls at every stage. Payments for salaries and debt servicing are examples. For such payments, there are special expenditure control arrangements, usually executed by special centralized agencies. For example, control over salary payments is conferred mainly to a special division of the MOF (la Solde), which, in collaboration with the Civil Service Ministry and the Treasury, should make salary payments only to civil servants whose existence is verified. In practice, due to the lack of maintenance of, and/or integration with, personnel records, salary control is often weak. As a result, salaries have been paid to nonexistent or "ghost" workers. A similar problem has arisen in anglophone African countries (Lienert and Modi, 1997).

Special debt agencies, responsible for orderly debt payments, have been established in some francophone countries. ${ }^{20}$ These agencies-Caisses Autonomes

d'Amortissement (CAAs) - were set up (and later abandoned in some countries), largely to assure that external debt was serviced, as the Treasury not always able to perform this function effectively. Despite the setting up of CAAs, payment arrears on debt, especially external, occured in several francophone countries - a reflection of poor internal control and management, and/or lack of coordination with the MOF (notably with the Trésor).

\section{Payment}

In anglophone countries, payment is either centralized or decentralized. The basic model at independence was a centralized payments system, with sub-treasuries for regional payments. However, in some countries, both payment authorization and actual payment was devolved to spending ministries or units. Such is the case in Malawi and Zambia. In others, payment remains centralized (e.g., The Gambia, Lesotho, Tanzania). In the case of Tanzania, the re-centralization of payments in 1996 facilitated the installation of an integrated computerized accounting and payment system.

In francophone countries, it would be inconceivable for payment to be made outside the Treasury. Consistent with its inheritance and the strong centralized role played by the Treasury in France, all payments are effected by the Treasury.

${ }^{20}$ See Box 5 of Bouley, Fournel, and Leruth (2002). 


\section{Internal Control and Internal Audit ${ }^{21}$}

In anglophone countries, internal control is semi-decentralized. In several countries, the officers who perform the internal control function in spending ministries are employees of the Internal Audit department of the MOF (e.g., in The Gambia, Kenya, Uganda, Malawi). These officers are outposted to spending ministries to ensure compliance with financial regulations issued by the MOF and are viewed by AOs as agents of the MOF, as they report principally to the MOF, with copies of reports addressed to AOs. In a few countries (e.g., Ghana until recently), spending ministries recruit and manage their own internal auditors to assist the $\mathrm{AO}$ in financial management. In such countries, internal auditors' reports are prepared principally for the AOs, with copies for the Internal Audit Department of the MOF.

Francophone countries MOFs have a strong system of centralized internal control. At the expenditure commitment stage, the contrôleur financier, who may be outposted to the spending ministry (SM), checks the regularity and conformity of the commitment against budget appropriations. The ordonnateur issues a payment order to the treasury, for which a second visa (approval) is required from the contrôleur financier. A third control is made by the treasury accountant, who makes the payment. Internal control is therefore highly centralized as all of the above are MOF staff.

In addition to an elaborate system of internal control, most francophone countries have established an internal audit unit-l'Inspection des finances. These units are also located in the MOF, but they are highly placed, generally attached to the Minister of Finance's Office (Cabinet du ministre). The inspectorates have broad responsibilities for internal audit, as opposed to the internal control activities of contrôleurs financiers and ordonnateurs who perform routine checking. The inspectorates not only audit the financial management units located in the MOF (tax/customs administrations, budget department, treasury), but they can audit any public sector entity. These inspectorates generally report directly to the Minister of Finance. Some anglophone countries (e.g., Ugnda) also have an Inspectorate Divison in the MOF, with functions similar to those of l'Inspection des finances).

In some francophone countries, an even higher-level agency (Contrôle Générale d'Etat), with investigative powers and responsibilities broader than Finance Inspectorates, has been established. These high level inspectorates perform audits internal to the Executive branch. The closest equivalent agencies in anglophone countries are the Anti-Corruption Offices/Commissions that have been established in several countries (e.g., Kenya, Nigeria, Uganda, see www.undcp.org/corruption_projects).

${ }^{21}$ For fuller details on the operation of internal control and audit in Africa, see Diamond (2002). For a distinction between internal control and internal audit, see Chapter 10 of OECD (2001). 


\section{Government ACCounting, Banking ANd FisCAL REPORTing}

This section examines the similarities and differences in the accounting systems, summarized in Box 3. It then discusses the common problem of not producing timely accounts in both regions.Banking arrangements are also reviewed.

\section{Box 3. Similarities and Differences in Accounting and Banking Arrangements}

\section{Similarities}

- Cash basis for accounting.

- Poorly maintained accounting records that often lack reconciliation with bank records.

- Annual accounts not available within statutory deadlines.

\section{Differences : francophone countries have:}

- A more formal and complex accounting framework, with treasury balances an integral part of the system.

- $\quad$ Accounting centralized in the MOF.

- A complementary accounting period for accounts closure.

- A single treasury account (with some exceptions).

Differences : anglophone countries have:

- $\quad$ spending ministries responsible for preparing annual accounts and providing inyear accounting reports to the MOF.

- a multiplicity of government bank accounts (some countries).

\section{A. Accounting Framework}

The francophone countries' accounting system is typically specified formally by decree, or even law. ${ }^{22}$ These decrees/laws are modeled largely on the Public Accounting Decree adopted in France in 1962 (which is under revision given the intention of France to move to accrual accounting). In contrast, Accounting Regulations in anglophone countries are prepared by the MOF, and hence can be modified more easily.

The French-based accounting system is more complete, incorporating some accrual information. Although cash accounting, as opposed to accrual accounting, is used in both PEM systems, in the anglophone countries, a single-entry accounting system is followed. In particular, the accounting system does not require regular reporting of financial assets and liabilities within the year (although external and domestic debt is usually recorded, with varying degrees of quality). In contrast, in francophone countries, as from the ordonnancement stage-for expenditures, this means after payment orders are received in the Treasury-the accounting system becomes double-entry. Both revenues and expenditures, as well as financial assets and liabilities, are recorded

${ }^{22}$ In Mali, besides a decree, an Accounting Law has been adopted. 
according a well-specified chart of accounts. ${ }^{23}$ This allows identification of bills that have been sent to the Treasury for payment, but have not been paid. Such information is not obtainable from the accounting system of the anglophone African countries. Although special recording arrangements have been put in place (e.g., in Malawi, Uganda, Zambia) to capture this information that is missing from the accounting system.

Spending ministries in francophone countries are not responsible for preparing accounts, which are centralized in the MOF. Nonetheless, the gestionnaires de crédits in line ministries should maintain accounting records of expenditures at the commitment (engagement) and verification (liquidation) stages; their records for commitments should be cross-checked with the "master" records held in the MOF, usually the Budget Department (or its Financial Controllers). In practice, the quality of accounting information at the pre-payment stage is variable in francophone African countries, although it is often better than treasury information.

\section{B. Annual Accounts}

In the anglophone countries, one of the responsibilities of Accounting Officers is to prepare and submit annual accounts to the Accountant General (AG). The main account is the "Appropriation Account," which shows actual expenditures against expenditures appropriated by Parliament. The AOs also have to prepare statements on: (1) the annual revenues collected by his/her ministry, (2) the amounts outstanding for loans for which the $\mathrm{AO}$ is responsible, (3) other statements, as specified by the AG. The AG consolidates all departmental accounts into the Annual Accounts of Government. These are forwarded to the the Auditor-General for independent external audit (see section V). The MOF's Financial Regulations reiterate the statutory deadline for submission by the AG of the annual accounts to the Auditor General. Although the prescribed period for completing the accounts is usually six months, ${ }^{24}$ in practice, long delays are experienced in some countries.

Spending ministries in francophone countries are absolved of the responsibility of preparing annual accounts. The preparation of annual accounts by the MOF is a more complex process: a double set of accounts are prepared. First, the comptes administratifs, providing details of revenues and expenditures up until, and including, ordonnancement need to be prepared. This task is generally delegated to the Budget Department. Second, the Treasury's accounts-les comptes de gestion-show the account balances and transactions at the encashment stage for revenues and cash payment stage for expenditures. In the comptes de gestion, there should be a reconciliation of stocks and flows: opening treasury balances for a new fiscal year should be equal to the opening treasury balances of the previous fiscal year, plus all flows during the previous fiscal year. Any discrepancies between closing balances from one year and opening balances of a new fiscal year should be fully explained. However, such reconciliations are seldom

${ }^{23}$ There are 9-10 standard "classes" of accounts, based on the system still used in France.

${ }^{24}$ A further three months is generally prescribed for their auditing. 
performed, as the administrative capacity and/or willingness to operate the accounting system as prescribed in regulations is often lacking.

There are important differences concerning the delays for closing of annual accounts. In the anglophone countries, accounts are generally closed on the final day of the fiscal year; in practice, a few days may be allowed for processing transactions that have occurred at the end of the year. In contrast, for the francophone countries, there is a relatively long complementary period for closing the accounts. Payment orders may be issued up until the final day of the fiscal year. ${ }^{25}$ To allow actual payments to be made after the end of the fiscal year, a complementary period of 2-3 months is authorized (payments for the preceding year can be made after December 31 but recorded as if they had taken place before January 1 of the new year). Long complementary periods have the inconvenience of keeping two books of accounts open for the early months of a new fiscal year. In some countries (e.g., Togo), extensions to the mandated complementary period are made. As a result, the processing of transactions relating to the previous fiscal year continue for several months after the end of the fiscal year.

Both regions have suffered from a common problem of nonavailability of annual accounts. One minimum standard of the IMF's Code of Good Practices in Fiscal Transparency is that final accounts should be presented to Parliament within 12 months of the end of the fiscal year. This implies that accounts must be presented to the external audit agency 6-9 months after the end of a fiscal year. There are very few African countries that meet this deadline: in a sample of 17 francophone and anglophone countries, only two countries (Chad and Uganda) presented their annual accounts to Parliament within this deadline. ${ }^{26}$ In some anglophone countries (e.g., The Gambia and Lesotho) the delay has been 5-10 years, whereas some francophone countries have not produced a coherent set of annual accounts for many years, if at all (e.g., Madagascar, Mauritania). However, since the late 1990s, a number of francophone countries have begun to prepare annual accounts (e.g., Benin, Burkino Faso, Côte d'Ivoire, Cameroon, Guinea, Niger, and Senegal), after years of neglect in some cases.

\section{In-Year Reporting}

In anglophone Africa, regular reporting by the spending ministries to the MOF is critical for preparing in-year fiscal reports. The managers of spending agencies are required to ensure that Vote Books are kept up to date. These should be sent to the AG's Office for recording in the government general ledger. Spending ministries' Vote Books should be reconciled with the data maintained in the AG's office. In countries with manual recording systems, expenditure commitments are often poorly recorded and monthly expenditure reports are either not received in a timely fashion or are of poor quality. Only in a few countries have recording systems been computerized; these provide online data simultaneously in spending ministries and the MOF (e.g., Tanzania).

\footnotetext{
${ }^{25}$ In some cases, Ordonnancement may be closed earlier, e.g. December 15, rather than December 31.

${ }^{26}$ See IMF (2002).
} 
In francophone countries, in-year reporting is centralized in the Ministry of Finance. Upstream accounting - for expenditure commitments and payment order issuance - is the responsibility of the Budget Department (ordonnateur or contrôleur financier). ${ }^{27}$ Downstream accounting records-expenditure payments (as well as revenues) - are maintained by the Treasury. However, at the payment stage, transactions are not necessarily posted to final accounts with the same nomenclature as the budget, as the accounting nomenclature (at the Treasury) is not necessarily identical to the budgetary nomenclature of the Budget Department. As a result, it is often difficult to track payments of specific budgetary expenditures.

Comprehensive reconciliation of accounting ledger data with bank account records is not always undertaken systematically, thereby undermining the reliability of monthly fiscal reports of both regions. Nonreconciliation of data appears to be more acute in anglophone countries, especially those with a multiplicity of bank accounts (see Section $\mathrm{D}$ below). This is despite the provisions of financial regulations, which lay down the need for regular reconciliation.

\section{Government Banking Arrangements}

In principle, a Treasury Single Account (TSA), held at the central bank, is an integral component of both systems. In practice, there are a number of "special" accounts outside the TSA, for which cash balances are not available for general government spending. In both regions, donors-who finance much of the capital expenditure-typically require that a separate bank account be opened, usually in a commercial bank, as they are distrustful of payments being effected by local treasuries.

In the anglophone countries that have decentralized the payment function, the number of government bank accounts may exceed 1,000 (e.g., Zambia). In such countries, each ministry may have a separate account for each type of spending. Accounts have been opened in a multiple number of commercial banks, in addition to those opened at the central bank. Commercial banks are not used this way in francophone countries. The Treasuries of francophone countries ensure that funds are pooled-not only those of central government, but also those of local governments, subvented agencies and public enterprises. In principle, this helps to manage cash balances more effectively.

Dedicated funds, each with a separate bank account, are commonplace in both regions. Specific Laws may have set up autonomous agencies which receive earmarked government revenues for dedicated spending. For example, Road Funds managed by boards independent of the MOF have been set up (Potter, 1997). Off-budget funds for receiving oil revenues were, in the past, a source of nontransparency in oil producing countries in both regions (e.g., Cameroon, Nigeria). In the francophone countries, there

\footnotetext{
${ }^{27}$ Practices vary in the countries where the financial control function is not under the MOF. For example, in Madagascar, the most reliable source of information on commitments is from the Financial Control unit under the Presidency, although the data are not fully reconciled with the records of the Budget Ministry (there is also a Ministry of Finance in Madagascar). In contrast, in Mauritania, the Financial Control entity, under the Presidency, relies on the computerized records of the Budget Department of the MOF.
} 
may be separate bank accounts associated with "budget annexes" or "special treasury accounts" (e.g., Senegal). The existence of many special accounts, whose balances are not pooled, results in ineffective cash management, as unremunerated deposit balances may build up, and, at a same time, the government is borrowing at high interest rates. This is especially the case in anglophone countries, where treasury bill markets are relatively well-developed, and where the central banks rather than the MOFs play a central role in issuing treasury bills.

\section{EXternal Audit and Parliamentary Control}

The external audit agencies reflect the historical inheritance from the corresponding institutions in the United Kingdom and France. In the anglophone African countries, Offices of the Auditor General (AuG) have been set up. A major task of the AuG is to prepare an annual report on the government's accounts, for review by the Public Accounts Committee of Parliament. The Auditor General is usually appointed by the country's President, conjointly with Parliament. In most francophone countries, Chambers of Accounts (Chambres des comptes) have been set up (e.g., Benin, Chad, Guinea, Madagascar, Mali); in a few there is no external audit agency. ${ }^{28}$ The inherited external audit institution in francophone countries is seen as part of a triple set of controls: administrative, jurisdictional, and parliamentary.

Unlike the British-based system, the francophone countries' Chambers of Accounts are legally independent of both the executive and the legislative. They are under the judiciary branch of government, being presided by a magistrate. However, as in France, the President of the Chamber of Accounts is appointed solely by the executive branch. The Chamber of Account's annual report is normally transmitted to Parliament, as well as to the President of the country. In some countries, Parliament does not receive the entire external audit report. ${ }^{29}$

Auditor Generals have financial independence, whereas Chambers of Accounts are dependent on the Supreme Court for their annual budgets. In anglophone countries, the AuG's salary is a statutory expenditure-Parliament cannot alter its amount. As the Accounting Officer for his Office, the AuG oversees the preparation of the annual budget for his Office, and submits it to the MOF (which may cut it). After end-year, the AG defends his budget outcome in Parliament. A different situation prevails in most francophone countries: since the Chamber of Accounts is only one of several chambers of the Supreme Court, its annual budget is not determined exclusively by its president. For this reason, some countries (e.g., Burkino Faso, Senegal) have set up financially independent Courts of Accounts and the WAEMU Commission is encouraging the other six member countries to transform Chambers of Accounts into independent Courts of Accounts. However, the case of Burkino Faso illustrates that this is not an easy process: the Constitution needed to be changed in 2001 to establish an independent Court. Mali, for instance, decided in 2001 to postpone the required constitutional change needed to

\footnotetext{
${ }^{28}$ For example Cameroon, although an external audit agency is now envisaged.

${ }^{29}$ For example, in Mauritania, only parts of the annual report is required to be sent to Parliament.
} 
transform its Section des Comptes (of the Supreme Court) into an independent Court of Accounts.

In the francophone system, the Chamber of Accounts is required to issue a certificate of conformity that indicates that, in the annual accounts, payment orders received by the Treasury are identical to payment orders issued. The usefulness of such a requirement is questionable, since, in principle, the comptes de gestion should already correspond to the comptes administratifs as the Treasury is supposed to have verified the consistency between payment orders received and actual payments.

In francophone countries, Parliaments verify-or should verify-the annual accounts by a formal law. The Budget Execution Law or Loi de Règlement (LdeR) records the outturns for revenues and expenditures, and compares these with the budget estimates, inclusive of any modifications to the original budget-either via virement or by supplementary estimates. In principle, the LdeR law can only be presented to Parliament once the Chamber (Court) of Accounts has certified that the comptes des gestion and comptes administratifs are fully compatible. In practice, LdeR laws may not be adopted at all (because annual accounts are unavailable), or adopted without verification by the Chamber (Court) of Accounts (because it has low administrative capacity).

In both regions, the follow up mechanisms for implementing the recommendations of annual reports of the external audit agencies are inadequate. This is not so much a problem of the system design, but rather the lack of material and human resources devoted to the external audit function. In anglophone countries, when (if) the AuG's report is presented to the legislative branch, it may be reported in the media, but then quickly forgotten. Although AOs are required to follow up on the recommendations of the $\mathrm{AuG}$, by presenting written reports to the Public Accounts Committee of Parliament on the actions taken to address concerns raised, enforcement of such provisions is weak. The MOF is also supposed to report action taken to implement the AuG's recommendations, but this is seldom done.

In the francophone countries, the focus is on the accuracy of the accounts and the approval by Parliament of any difference between the original budget and the actual outturn. Although the Chamber (Court) of Accounts has authority to hold public accountants personally responsible for any deliberate misreporting, there is seldom any prosecution. If misdemeanours are made by ordonnateurs - those who commit government to pay - the Chamber of Accounts has no authority to initiate actions against them. In France, there is a second body, the Court of Budget and Financial Discipline, to deal with non-Treasury officials who inappropriately manipulate funds. In Africa, such courts have not been set up (Senegal is the only exception-such a court has been established under the independent Court of Accounts). 


\section{IS ONE PEM SYSTEM SUPERIOR?}

The previous sections show that the main differences in the two PEM systems are in budget execution, fiscal reporting, and audit. For budget preparation, similarities dominate, although it could be argued that, with respect to investment spending, the francophone system has a favorable feature-it allows carryovers of unspent commitments and facilitates better forward planning of investment expenditures.

This section examines more closely the distinctive features of the "British-" or "Frenchbased" PEM systems, and discusses whether they contribute to better financial management. It then compares the common weaknesses of the two PEM systems and suggests that there may be additional factors at play that dominate the mediocre performance of PEM systems in both regions.

\section{A. Potential Strengths of the Individual PEM Systems}

The key distinctive features of the two systems are summarized in Table 1. In the discussion below, it is argued that the French-based PEM system should, in principle, give better results for achieving macroeconomic stability, an important objective for any PEM system. Neither PEM system is geared for obtaining efficiency objectives. Discussion of results-oriented budgeting is beyond the scope of this paper, as performance-oriented budgeting is yet to be tested in most African countries.

\section{Expenditure control and payment arrears}

It could be argued that the centralized French-based system, with a priori controls by the MOF at each stage of the expenditure process, results in better expenditure control. In the French-based system, the MOF takes a lead role in controlling expenditures at the prepayment stage, and in theory, it is able to integrate information on expenditure commitments into the cash planning process. Such strong central surveillance could be considered necessary to counteract weak administrative capacity and limited accountability of line ministries' budget managers.

In view of this, expenditure commitment control systems are being put in place in various anglophone African countries (e.g., Malawi, Tanzania, ${ }^{30}$ Uganda, Zambia). However, there has been mixed success in effectively controlling expenditure commitments and, especially, in preventing expenditure payment arrears, which is a pervasive problem in several anglophone countries. This reflects the generalized lack of financial discipline. In principle, expenditures could be controlled by warrant withdrawal. In practice, this instrument is rarely used. ${ }^{31}$

\footnotetext{
${ }^{30}$ In Tanzania, expenditure commitment control is computerized. In the other three countries, manual systems have been, or are being, put in place to control expenditure commitments.

${ }^{3 !}$ Financial regulations of anglophone countries usually provide that the unspent balance of any warrant may, at any time, by withdrawn by the Minister of Finance. Once a withdrawal warrant has been issued, the Accounting Officer may not permit expenditure to exceed the remaining balance.
} 
Table 1. Distinctive Features that are Potential Strengths of PEM Systems

\begin{tabular}{|c|c|c|}
\hline Area of PEM: & Anglophone Countries & Francophone Countries \\
\hline Expenditure control & $\begin{array}{l}\text { Spending ministries are } \\
\text { primarily responsible for } \\
\text { expenditure control. }\end{array}$ & $\begin{array}{l}\text { The Ministry of Finance exercises ex ante } \\
\text { expenditure control prior to payment. }\end{array}$ \\
\hline Internal audit & $\begin{array}{l}\text { Internal audit partly } \\
\text { decentralized to spending } \\
\text { ministries. }\end{array}$ & $\begin{array}{l}\text { Centralized internal control and internal } \\
\text { audit, which are strongly ingrained in the } \\
\text { system. }\end{array}$ \\
\hline $\begin{array}{l}\text { Accounting system } \\
\text { and fiscal reporting }\end{array}$ & $\begin{array}{l}\text { Simpler accounting; less } \\
\text { emphasis on split between } \\
\text { ordonnateur and comptable; } \\
\text { spending ministries are } \\
\text { responsible for preparing the } \\
\text { primary records of } \\
\text { expenditure commitments and } \\
\text { payments. }\end{array}$ & $\begin{array}{l}\text { Accounting framework is logical: changes } \\
\text { in treasury balances equal flows of } \\
\text { transactions. Expenditure is recorded and } \\
\text { reported at each stage; accounts payable } \\
\text { at the treasury can be identified. } \\
\text { Centralized accounting should facilitate } \\
\text { fiscal reporting. }\end{array}$ \\
\hline $\begin{array}{l}\text { Banking } \\
\text { arrangements }\end{array}$ & & $\begin{array}{l}\text { Greater centralization of bank accounts in } \\
\text { central bank (no payment by spending } \\
\text { ministries). }\end{array}$ \\
\hline Fiscal rules & & $\begin{array}{l}\text { To support the fixed exchange rate regime } \\
\text { of the CFA franc, borrowing from the } \\
\text { central bank has always been limited } \\
\text { (now it is proscribed). }\end{array}$ \\
\hline $\begin{array}{l}\text { External audit and } \\
\text { parliamentary control } \\
\text { Responsibility to } \\
\text { Parliament }\end{array}$ & $\begin{array}{l}\text { Auditor General's position is } \\
\text { independent (it is also a } \\
\text { statutory expenditure). } \\
\text { Heads of spending agencies } \\
\text { and/or Ministers must defend } \\
\text { budget outcomes in } \\
\text { Parliament. }\end{array}$ & $\begin{array}{l}\text { External audit agency is independent of } \\
\text { both the executive and legislative } \\
\text { branches. }\end{array}$ \\
\hline
\end{tabular}

In some francophone countries, when revenues fall short of projections, expenditure commitments are closed earlier than usual. Should it become transparent during the fiscal year that there is insufficient cash for meeting all payments, the Budget Department of the MOF can instruct ministries to no longer commit expenditures after a certain date (e.g., mid-November instead of end-November). Similarly, the MOF can stop payment order issuance (ordonnancement) before the close of the fiscal year (e.g., midDecember). Although these tools have been used in several francophone countries, their effectiveness has been limited, because only a small proportion of discretionary expenditures is postponable, important exceptions are accorded, and the instructions are not always fully enforced. Worse, in several countries, there is not an awareness of the need to freeze commitments, due to defective cash management procedures, poor accounting information, or a lack of willingness to firmly control expenditures. 


\section{The problem of expenditure payment arrears is also pervasive in several}

francophone countries. Whereas in a few countries, nearly all government invoices are paid on time (e.g., Benin, Mali, Mauritania), in other countries, the size of expenditure arrears has surpassed the worst-case anglophone countries, even exceeding 10 percent of GDP in Djibouti and Togo. This suggests that there are other important factors at play in francophone countries that are preventing effective control of expenditure commitments.

In several francophone countries expenditure arrears are partly caused by the bypassing of the normal expenditure control procedures. Because the system of a priori control by the MOF on expenditure at both the commitment and payment order (ordonnancement) stages is complex, contains redundancies, and is slow to permit payment for goods or services, francophone countries have introduced, or overexploited, "simplified" expenditure procedures that bypass the central controls (Box 4).

\section{Box 4. Exceptional Expenditure Procedures in Francophone Countries}

- Direct payment by the treasury (ordres de paiement), under which the treasury is directed to make payment prior to the a priori controls on commitments and payment order issuance.

- Imprest accounts (caisse d'avances) which are usually reserved for small or specific expenditures, under tightly defined rules. In some countries, ministries use this procedure for many expenditures of a particular type (e.g., all defense expenditures in Madagascar).

- Special accounts/funds, used for payments that do not require prior approval at the payment order stage.

The main objective of these procedures is to accelerate payment, since the "normal" procedure for expenditure approval and control is burdensome. For transactions conducted by these "exceptional" procedures, regularization of accounting is supposed to be rapid. In practice, such expenditures may never be recorded with clarity. In some countries, the "exceptional" procedures have become the standard way of executing nonsalary expenditure. ${ }^{32}$ Moreover, when arrears arise, the Treasury Director has discretion as to which bills should be paid first, which is an open door to corruption in the payment process.

The lack of feedback from the Treasury to the Budget Department and spending ministries is a particularly acute problem in francophone countries. The split between ordonnateur and comptable has an unfortunate consequence. The Budget Department considers that its work is complete when it sends documents to the Treasury for payment. The "lack of resources" problem is perceived by the Budget Department to be the Treasury's problem alone. There is no feedback from the Treasury to the Budget Department. When there are shortfalls in cash revenues, instead of examining ways by which the rate of approval of expenditures at the commitment stage could be slowed, the

${ }^{32}$ For example, a World Bank mission to Benin found that a considerable portion of nonsalary expenditures were executed this way. 
Budget Department disavows responsibility for unpaid bills. In these circumstances, unpaid suppliers approach the Treasury directly, to hasten payment, perhaps with some added incentives to ensure prompt writing of the necessary treasury check. The lack of feedback between the Accountant General's Department and Budget Department is also a problem in anglophone countries. In both regions, Budget Departments fail to provide good guidance to the Treasury concerning future payments in the pipeline.

Ineffective cash management also contributes to the arrears problem. Even in the relatively well-managed francophone countries, expenditure commitment "control" is simply a check against annual budget appropriations. With the possible exception of closing commitments earlier than usual at end-year, budgeted expenditure commitments are not adjusted downward during the year should cash not be available. This is partly due to inadequate coordination between the Budget Department and the Treasury.

\section{Internal audit}

It could be argued that the centralized internal control and audit systems of the francophone countries results in better financial management than the decentralized systems in anglophone countries. First, the internal control mechanisms associated with expenditure control are very well implanted in the francophone countries: a body of Financial Controllers, under the Budget Department of the MOF, is an essential part of the expenditure control system in all countries. In contrast, internal audit divisions of MOFs - which provide internal auditors to SMs of anglophone countries-is usually a less prominent part of the PEM system. Second, in the francophone countries that have established Inspections des Finances, there is potential for investigating and reporting on malpractices in the PEM system as a whole. Few anglophone countries have such Inspectorates. Third, when human capacity is weak in spending ministries, and the rule of law/regulations is not respected, strong central control is needed-decentralization of the internal audit function requires well-trained teams of auditors, with effective oversight from the management of SMs. This is usually lacking in anglophone countries.

However, there is little evidence to suggest that francophone countries have more effective internal audit. According to surveys conducted in 10 francophone countries, only one was deemed to have effective internal audit. ${ }^{33}$ In part the result for francophone countries is because Financial Controllers may lack the necessary independence and/or willingness to enforce financial regulations. For example, it is well known that not all goods or services are delivered according to contractual conditions, suggesting that Financial Controllers may collude with gestionnaires de crédit, suppliers, and/or receiving officers (comptables matières) who certify that goods or services have been delivered, when in fact full delivery has not taken place. There may also be little effective control over overinvoicing. Concerning l'Inspection des finances, these bodies may not have been provided with sufficient financial, material, or human resources, or may often lack the necessary dynamism, to carry out their functions fully.

${ }^{33}$ In the same survey, only one out of six anglophone countries had effective internal audit. Internal audit was found to be one of the areas of the PEM system of HIPC countries that needed the most upgrading. See item 9 of Figure 2 of IMF (2002). 


\section{Accounting system and fiscal reporting}

It could be argued that the francophone countries' accounting system contributes to better financial management. In principle, the French-based accounting system is capable of providing budget managers with richer and more consistent information for financial management. First, the accounting framework is laid out comprehensively in accounting regulations and a formal chart of accounts (very similar to that used in France). The accounting system includes some accruals-basis information, with financial assets and liabilities identified in accounts. Cash flow statements are, in principle, reconciled with treasury balances. In anglophone countries, accounting instructions and charts of accounts also exist, but the partial accrual information is missing. Second, in the francophone system, expenditure is recorded and reported at least three stages: commitment, ordonnancement, and payment. In addition, spending ministries hold records at the accrual (liquidation) stage-when economic transfer takes place. In the anglophone countries, at best, commitments and payments are recorded. Third, the francophone accounting system is double-entry for treasury transactions, enabling accounts payable at the Treasury to be identified. It is impossible to obtain data on expenditure arrears from traditional anglophone accounting systems. Fourth, since accounting is centralized, timely fiscal reporting should be easier.

The potential advantages of the francophone countries accounting systems are not exploited, mainly because it has proven difficult to operate and maintain solid accounts. The complexity of the accounting system, operated in most countries on a manual basis (until recently), has resulted in very poor accounting records being kept in most francophone countries. A particular problem is the artificial split between ordonnateur and comptable, which has resulted in fragmentation, and even inconsistencies, in accounting information. In most countries, Budget Departments maintain the expenditure records for commitments and ordonnancements, although some countries have institutional fragmentation even at this level. ${ }^{34}$ While Treasuries maintain - or should maintain the "downstream" accounting records, including the general ledger from which fiscal reports should be generated-in many countries, timely and consistent treasury balance information is unavailable. Additionally, because several francophone countries have maintained different classification systems for the "upstream" and "downstream" expenditure records, ${ }^{35}$ it is extremely difficult to track expenditure at each stage.

Besides the fragmentation of responsibilities within the MOF, the noninvolvement of spending ministries in maintaining the primary records deprives the MOF of maintaining expenditure records at the crucial accrual (liquidation) stage. If

\footnotetext{
${ }^{34}$ In some countries, an Ordonnancement (or "Finance") Department has been established, separate from the Budget Department (e.g., Togo). Also, Financial Controllers in some countries are outside the MOF (e.g., under the Presidency), and may keep independent accounting records.

${ }^{35}$ The lack of consistency between the budget and the accounting nomenclatures can be traced to the system used in France until recently.
} 
francophone countries begin to move towards implementing full accrual accounting, it will be a challenge - not only in francophone Africa, but also in France ${ }^{36}$ - to change institutional arrangements so that accounting is devolved to SMs, as is presently the case in anglophone countries.

Implementation of the sanction system is deficient in both regions. In the francophone countries, treasury accountants (comptables publics) have "pecuniary and personal responsibility" to produce timely, verifiable, and comprehensive accounts, as well as to make payments in accordance to financial regulations. In practice, there is very little sanctioning of treasury accountants who abuse the rules. Similarly, in anglophone countries, there are provisions for sanctioning accountants, but implementation of relevant provisions is often lacking.

The francophone sanction system has a flaw. More importantly, sanctions are rarely applied in both regions. In the francophone countries, the entire responsibility for preventing abuse in financial management rests on the shoulders of the comptables publics, whose accounts are judged by an independent agency-the Chamber (Court) of Accounts - to detect any malpractices. Since public accountants are responsible for checking the validity of prepayment documents received in the Treasury, they alone bear "pecuniary and personal responsibility". In contrast, the regulations usually impose no sanctions on the upstream players - especially the ordonnateurs of the MOF's Budget Department or of spending ministries (in the few cases where ordonnancement has been decentralized). In contrast, the Accounting Officers in anglophone countries are, in principle, responsible for preventing overspending (Box 2). Although there may be some sanctions in financial regulations, such as the preparation of a written report to the Minister of Finance when overspending occurs, such provisions are often not enforced. In many anglophone countries, the President of the country appoints the Accounting Officers, and, should abuses occur, AOs are understandably reluctant to report.

\section{Banking arrangements}

The centralization of all bank accounts at the central bank, with no payments being made directly by spending ministries, appears to be another advantage of the PEM system in francophone countries. Some anglophone countries too, have reinstituted a central payment system from a TSA, as this contributes to more effective cash management and reduces the scope for maintaining unutilized balances in multiple bank accounts. Despite this advantage, both anglophone and francophone countries abandon this principle for donor-financed expenditures, for which commercial bank accounts controlled by donors, not Treasuries, are used. Also, in francophone countries, public enterprises are often obliged to deposit any surplus funds at the Treasury; to the extent that the Treasury allows enterprise deposit accounts to go into overdraft, the government is lending to these enterprises in a nontransparent manner. ${ }^{37}$

\footnotetext{
${ }^{36}$ The respective roles of the MOF and spending ministries in implementing accrual accounting in France, following adoption of a new Organic Budget Law in August 2001, are still being clarified.

${ }^{37}$ See Bouley et. al. for a fuller discussion of "le circuit du trésor".
} 


\section{Fiscal rules}

A unique feature of the francophone countries is the very strict limit on government borrowing from the central bank, in order to support the fixed exchange rate vis-à-vis the French franc, and since 1999, against the euro. Until 2000, the total government borrowing limit from the two regional central banks of the CFA franc zone was fixed at 20 percent of tax revenues; since then, government borrowing from the central banks is prohibited. In fact, WAEMU countries are now obliged to repay outstanding government credits. This policy contributed to the low inflation rates in francophone countries. Whereas this fiscal rule has had a favorable impact on macroeconomic stability, it has resulted in cash shortages and banking crises in francophone Africa, as formal rules were bypassed in an indirect way. ${ }^{38}$ In contrast, some anglophone countries experienced bouts of high inflation in the early $1990 \mathrm{~s}$, due to central bank financing of unplanned fiscal deficits; at that time, it was relatively easy to exceed any limits on "ways and means" advances from central banks.

\section{External audit and Parliamentary control}

It could be argued that the system of external audit and parliamentary control in anglophone countries produces better PEM management. First, the Auditor General's Offices have had a long tradition of preparing annual reports. In contrast, the Chambers of Accounts in francophone countries are more recent creations. Second, the Chambers of Accounts concentrate very heavily on the legality of expenditures and compliance with financial rules, and review of the draft LdeR. Third, Public Accounts Committees (Commissions des finances) of Parliaments-which are essential for follow up of external auditors' recommendations-have been more active in the democratic anglophone countries than their counterparts in francophone countries.

In practice, in both regions, the external audit function has not been accorded the priority it deserves. In both regions, external audit offices are often deprived of the necessary financial, human and material resources for carrying out their mandates. Very few African countries are able to present audited annual accounts to Parliament within 12 months (see IMF (2002)). Finally, when reports become available, they are not acted upon with the seriousness they deserve.

\footnotetext{
${ }^{38}$ Masson and Pattillo (2001) decribe the indirect deficit financing in CFA franc zone countries. "Much activity was initially kept off the fiscal accounts, as governments pushed state-owned banks to make loans to public enterprises." These banks were able to obtain refinancing from the BCEAO at concessional rates.
} 


\section{B. Common Weaknesses of PEM Under Both Systems}

The francophone countries' PEM systems appear to have performed slightly better in attaining benchmarks for budget preparation, about the same for budget execution, and considerably worse for fiscal reporting. However, differences are not significant: statistical tests indicate that one cannot confirm (at standard confidence levels) the hypothesis that the francophone and anglophone countries' averages shown in each panel of Figure 1 are dissimilar.

Thus, any unique and favorable features of the francophone countries' PEM system have not contributed to a consistently better performance. The main area where the francophone countries were slightly better than anglophone countries was for budget preparation. There are potentially two areas where the francophone countries' PEM systems are, a priori, advantageous. First, there is a distinction between existing and new policies, and second, there is a requirement for medium-term investment projections. However, the "better" results for budget preparation shown in Figure 1 are largely due to the francophone countries having relatively lesser recourse to extrabudgetary funds, and fuller integration of donor-financed expenditures into the budget, which typically have more complete budget classification systems. These differences, however, pale compared with the generalized weaknesses of budget preparation: both regions share the common problems of budgets not being comprehensive; inadequate classification systems; poor costing of specific expenditures; and an absence of MTEFs since the abandonment of national planning.

For budget execution, the two regions have broadly similar weaknesses, which are widespread. The francophone countries only showed more regular reconciliation of accounting and banking information. Again, both regions share common problems of poor expenditure control (with considerable variation in each zone), weak internal auditing systems, and incomplete reconciliation of accounting and banking data.

At first sight, it appears paradoxical that the francophone countries perform worse for fiscal reporting than the anglophone countries. It is argued above that, in principle, the French-based accounting and reporting system has several advantages over the British-based one. However, there appears to be a large gap between theory and practice. The poor overall performance of the francophone countries suggests that the accounting system is either too complex and archiac to operate and/or the rules are flouted. Francophone countries have had a particularly severe problem of not producing comprehensive and timely monthly and annual accounts. As a consequence, external audit institutions are unable to perform financial audits of annual accounts, let alone, more modern techniques, such as value-for-money audits. 


\section{Conclusions}

This paper analyses the differences between the PEM systems of anglophone and francophone Africa. Concerning the budget process, it may be concluded that:

- Budget preparation in the two regions are broadly similar, although there are two features of the francophone countries' system that arguably are advantageous relative to the system of the anglophone countries.

- There are significant differences in budget execution procedures between the two systems, centering particularly around the role and powers of the MOF and the degree of delegation of financial management to spending agencies.

- The francophone countries have the advantage of possessing a formal system of recording and controlling expenditures at the prepayment stages.

- Greater centralization of fiscal management in francophone countries should, in principle, produce better results for macroeconomic control, since throughout Africa, institutional capacity for operating budget execution and accounting arrangements in spending ministries is even more limited than at central (Ministry of Finance) level. On the other hand, for efficiency in budget managementresource allocation and obtaining results from budgetary programs - it could be argued that the anglophone countries' decentralized systems are conducive to better performance.

- The accounting system in the francophone countries also has some potential advantages, as it should produce more comprehensive information for fiscal management.

- The anglophone countries have inherited external audit arrangements that play a relatively more important role in the budget process than in francophone countries. In principle, supreme audit agencies in anglophone countries provide Parliament and the public with timely information on budget execution and the integrity of annual accounts.

Although the francophone countries' budget execution and government accounting systems have a number of potential advantages, these advantages do not appear to be fully exploited. The desirable distinctive features of the francophone PEM system is not accompanied by better aggregate expenditure control, as expenditure arrears in some francophone countries are higher than worst-case anglophone countries. Nor have the desirable features of the francophone accounting system-its greater centralization in the MOF and production of partial accrual accounting information (treasury balances)resulted in better fiscal reporting. On the contrary, when it comes to producing quality and timely in-year fiscal reports and annual accounts, the francophone African countries appear to have had severe problems. 
Thus, any distinctive strengths of the individual PEM systems do not appear to have influenced the performance of the system as a whole. In both regions, common weaknesses dominate. These weaknesses are widespread at every phase of the budget cycle. At the preparation stage, budgets need to be made more comprehensive, by incorporating all foreign-financed projects and extrabudgetary activities into an integrated national budget that has been formulated with firm expenditure ceilings derived from a medium-term budget framework. Expenditure control needs improving in nearly all countries, so as to prevent arrears.

An improvement in data quality appears to be a top priority. Full reconciliation of accounting and banking data, and more effective internal audit arrangements, are crucial. In both regions, the production of in-year fiscal reports and annual accounts is particularly weak. Although external audit bodies are constituted in nearly all countries, they have had a limited impact on improving PEM systems

To counter these weaknesses, it is essential that budget discipline is imposed at each stage of the budget process, otherwise expenditure overruns, the nonproduction of timely and comprehensive accounts, and ineffective internal and external audit activities will continue.

Since there are big variations within the francophone or anglophone groupings, it can be concluded that the disappointing features observed are due not to the PEM systems themselves, but in the way they operate. Thus, even if budget legislation and implementation instructions are clarified, in the absence of attitudinal changes by all players of the budget process - in the executive, legislative, and judicial branches of government - it is unlikely that significant improvements will occur. Critical actions will be those directed towards enhancing budget discipline and improving accountability of all those responsible for budget preparation, execution, reporting, and evaluation.

Strong political willingness to ensure that the existing rules are enforced with rigor and sanctions applied where necessary will be necessary to bring about lasting improvements in the PEM system in both anglophone and francophone Africa. Although this is largely a domestic issue, the international community can contribute to durable solutions by not only understanding more fully the actual operation of PEM systems, but also by withholding assistance to those countries which persistently fail to provide their taxpayers with adequate accountability mechanisms. 


\section{REFERENCES}

Attiogbe, K., 1999, "Le Processus Budgétaire au Togo," Direction du Budget, Ministère des Finances et des Privatisations, January.

Autin, J., 1971, "Initiation aux Finances Publiques, " Collection des cahiers de l'Institut International d'Administration publique, (Paris, Dunod).

Bouley, D. Fournel, J. and Leruth, L., 2002, "How Do Treasury Systems Operate in SubSaharan Africa," IMF Working Paper 02/58 (Washington: International Monetary Fund).

Brittain, Herbert, Sir, 1959, The British Budgetary System (London: Allen \& Unwin Ltd.)

Diamond, J., 2002, "The Role of Internal Audit in Government Financial Management: An International Perspective," IMF Working Paper 02/94 (Washington: International Monetary Fund).

Fölscher, A., ed., 2002, Budget Transparency and Participation: Five African Case Studies (Cape Town, South Africa: The Idasa Bookshop).

International Monetary Fund, 2001, Manual on Government Financial Statistics, available on IMF website, http://www.imf.org.

International Monetary Fund, 2002, "Actions to Strengthen the Tracking of PovertyReducing Public Spending in HIPCs," March 22, available on IMF website, http://www.imf.org.

Lienert, I., and Modi, J., 1997, "A Decade of Civil Service Reform in Sub-Saharan Africa," IMF Working Paper 97/179 (Washington: International Monetary Fund).

Lienert, I. and Sarraf, F., 2001, "Systemic Weaknesses of Budget Management in Anglophone Africa," IMF Working Paper 01/211 (Washington: International Monetary Fund).

Lord, G., 1973, “The French Budgetary Process," University of California Press.

Organisation for Economic Cooperation and Development, "Managing Public Expenditure: A Reference Book for Transition Economies," OECD, Paris, 2001.

Masson, P. and Pattillo, C., 2001, "Monetary Union in West Africa: An Agency of Restraint for Fiscal Policies?," IMF Working Paper 01/34 (Washington: International Monetary Fund). 
Moussa. Y., 2003, "Cross-country Comparison of PEM Systems in Francophone African Countries," IMF Working Paper, forthcoming, (Washington: International Monetary Fund).

Potter, B., 1997, "Dedicated Road Funds: A Preliminary View on a World Bank Initiative," Papers on Policy Analysis and Assessment 97/7 (Washington: International Monetary Fund).

World Bank, 1998, Public Expenditure Management Handbook (Washington: World Bank). 